Canadian Journal of Soil Science Revue canadienne de la science du sol

\title{
Effects of Oil Field Brine Wastewater on Saturated Hydraulic Conductivity of Smectitic Loam Soils
}

\begin{tabular}{|r|l|}
\hline Journal: & Canadian Journal of Soil Science \\
\hline Manuscript ID & CJSS-2016-0036.R1 \\
\hline Manuscript Type: & Article \\
\hline Date Submitted by the Author: & 23-Jun-2016 \\
\hline Complete List of Authors: & $\begin{array}{l}\text { Derby, Nathan; NDSU, Soil Science } \\
\text { Casey, Francis; North Dakota State University, Soil Science } \\
\text { DeSutter, Tom; North Dakota State University, Soil Science }\end{array}$ \\
\hline Keywords: & Salinity, Environmental quality, Hydraulic conductivity, Leaching, Drainage \\
\hline & \\
\hline
\end{tabular}

SCHOLARONE ${ }^{\text {IM }}$

Manuscripts 
TITLE

Effects of Oil Field Brine Wastewater on Saturated Hydraulic Conductivity of Smectitic Loam

Soils

AUTHORS

Nathan E. Derby, Francis X.M. Casey, and Thomas M. DeSutter

N.E. Derby, F.X.M. Casey, and T.M. DeSutter, North Dakota State University, Soil Science, NDSU-

Dept 7680, PO Box 6050, Fargo, ND 58108 
ABSTRACT

Spills of brine wastewater produced during oil well drilling are occurring more frequently in the Great Plains, resulting in crop production loss on affected soil. Remediation requires removal of salt from the topsoil, which might be accomplished by leaching to subsurface horizons or subsurface drains. A laboratory study determined the effects of brine on saturated hydraulic conductivity $\left(\mathrm{K}_{\mathrm{s}}\right)$ of four non-impacted surface soils from western North Dakota, USA. Repacked soil cores were subjected to saturated water flow, followed by one pore volume of brine. Subsequent saturated water flow leached brine from the soil and reduced $K_{s}$ as much as $97 \%$ (0.086 to $0.003 \mathrm{~cm} \mathrm{~h}^{-1}$ ) within $24 \mathrm{~h}$. Effluent total dissolved solids (TDS) approached $250000 \mathrm{mg}$ $\mathrm{L}^{-1}$ then declined $\left(5 \mathrm{mg} \mathrm{L}^{-1}\right)$ with continued leaching, but $\mathrm{K}_{\mathrm{s}}$ did not increase. Removal of soluble salts during leaching increased the relative sodium concentrations (ESP $>55)$, causing clay swelling/dispersion and reduced $\mathrm{K}_{\mathrm{s}}$. Post-brine gypsum application (11.2 $\left.\mathrm{Mg} \mathrm{ha}^{-1}\right)$ to replace exchangeable sodium with calcium did not improve $K_{s}$. This evidence suggests that if subsurface drainage is used for reclaiming brine-impacted soils that special attention be given to where dispersion/swelling is occurring, leaching water quality, and closely positioning calcium amendments within the high sodium zones.

Keywords: Brine spill remediation, soluble salts, exchangeable sodium, hydraulic conductivity, clay dispersion/swelling. 


\section{INTRODUCTION}

Oil production in North Dakota has increased from 100000 barrels per day to over 1000 000 barrels per day in less than a decade (ND Dept. of Mineral Resources 2014) due to the use of horizontal boring and hydraulic fracking technologies enabling extraction of oil and gas from the Bakken and Three Forks Formations in Montana, North Dakota, South Dakota, and Canada (USGS 2013). Along with the oil and gas, production water, also referred to as 'brine', is also produced. In 2007 in North Dakota, 3 barrels of brine per barrel of oil and 18 barrels of brine per million cubic feet of gas was produced (Clark and Vei 2009). This highly saline (predominately $\mathrm{NaCl}$ ) produced water is allowed to separate from the oil and is stored in above-ground tanks, and then injected into salt-water disposal wells. During storage and pumping of brine to injection wells, many spills of varying severity have been reported. In 2014 in North Dakota alone, more than 432 million barrels of brine was produced (increased from $<100$ million in 2001), of which 71000 barrels was spilled in 855 individual reported spills. From 2001-2014, more brine has been spilled each year than oil (ND Dept. of Health 2015; Daigh and Klaustermeier 2016).

Large brine spills, like the nearly 3 million gallons of brine that leaked from a pipeline into two creeks near Williston, North Dakota in 2015 (Jacobson 2015), attract much of the public attention. However, in addition to waterway contamination, brine usually first affects the soil where the spill occurs. The increased salt in the soil from the brine initially affects plant growth by preventing osmotic uptake of water by the plant roots or toxicity which kills the plant. This can result in complete soil sterilization for years or even decades (Murphy et al. 1988). Deterioration of soil physical properties is also affected by brine contamination. DeJong 
(1982) showed dispersion and swelling of soil cores in a laboratory setting after $\mathrm{NaCl}$ contamination. Subsequent leaching with gypsum-saturated water was only marginally effective at restoring percolation in their study.

Current remediation techniques include either removing the soil material and replacing it with uncontaminated soil or leaching the salts out of the rooting zone. Leaching has been aided by additions of organic matter, sources of calcium, and subsurface drainage (Harris et al. 2005; Sublette at al. 2005; Carter and Fanning 1964). However, after leaching the salts, there is danger of salinization of the subsoil or, if the water table is shallow, re-salinization of the topsoil due to capillary rise. Hence, it may also be necessary to provide a means of water removal such as subsurface drainage. Remediation by incorporation of calcium and/or organic matter and leaching with excess water has been somewhat successful in reducing the salinity. However, if the salinity in the topsoil is sufficiently reduced by leaching, there may be further danger of soil physical property damage due to dispersion and/or swelling caused by excess sodium on the exchange complex (He et al. 2015; Schofield and Taylor 1961). In the current study, we use saturated hydraulic conductivity as an indication of the deterioration of soil structure from dispersion and swelling caused by excess sodium.

Given the rapid rate of oil development in North Dakota and the region, and the increasing number of spills recorded each year, there is some urgency to disseminate as much information as possible on the effects of oil-field brine spills so that informed decisions can be made regarding remediation of these contaminated soils. The objective of this study was to determine the effect of oil-field brine on saturated hydraulic conductivity $\left(K_{s}\right)$ of a smectitic loam soil during and after contamination, and the implications for remediation. 


\section{MATERIALS AND METHODS}

Four bulk soils used for this study were collected with a shovel to a depth of $30 \mathrm{~cm}$ from two non-contaminated locations near Mohall, North Dakota, USA. Near both locations there are long-term brine-contaminated soils. Two soils, designated B_U and B_L, were described as Barnes loam (fine-loamy, mixed, superactive, frigid Calcic Hapludoll), and were taken from upper and lower landscape positions, respectively. Soil T_U was from an upland position and was described as Tonka silt loam (fine-smectitic, frigid Argiaquic Argialboll) in the Barnes-SveaTonka complex. Soil S_L was Svea loam (fine-loamy, mixed, superactive, frigid Pachic Hapludoll) in the Barnes-Svea complex and was from a lower landscape position. Even though the B_U and B_L were mapped (Order 2 survey) as the same soil type, the different landscape position indicated that the two soils may be different enough to warrant keeping them separate. The soil was air-dried, crushed, and sieved through a 2-mm screen. Particle size was determined using the hydrometer method (Gee and Bauder 1979). The $\mathrm{pH}$ and electrical conductivity (EC $\mathrm{E}_{1: 1}$ ) was determined on a 1:1 soil:water extract. The cation exchange capacity (CEC) was determined using the sodium acetate-ammonium acetate extraction method and analysis of sodium was done by atomic absorption (AA) spectroscopy (Soil Survey Staff 2011). The initial $\mathrm{pH}, \mathrm{EC}_{1: 1}$ and $\mathrm{CEC}$ of each soil and the average bulk density and pore volumes (based on weight of saturated cores) for all of the repacked cores are listed in Table 1. No field bulk density samples were taken, hence, no attempt to replicate a specific field bulk density was made. However, Web Soil Survey (Soil Survey Staff) lists the bulk density of the Barnes-complex soils as $1.35 \mathrm{~g} \mathrm{~cm}^{-3}$. 
The oil-field brine used for the study was collected from a pipe supplying an injection well in the vicinity of the soil locations. Chemical analysis of the brine was conducted by Midwest Laboratories, Inc. (Omaha, NE) using EPA standard methods and indicated a conductivity of $226 \mathrm{dS} \mathrm{m}^{-1}$ with the major ions being chloride (182 $681 \mathrm{mg} \mathrm{L}^{-1}$ ) and sodium (95 $738 \mathrm{mg} \mathrm{L}^{-1}$ ). Other analyte concentrations $\left(\mathrm{mg} \mathrm{L}^{-1}\right)$ included calcium (5 824), magnesium (1 454), sulfate (1216), phosphorus (8.5), potassium (3 575), bicarbonate (238), and boron (170). The total dissolved solids (TDS) was measured by the authors by evaporation to be $308820 \mathrm{mg}$ $\mathrm{L}^{-1}$. The brine was mostly free of petroleum products, however, a slight oily residue was present but removed prior to starting the experiments.

Tempe cells were assembled using the modification described by Sommerfeldt et al. (1984), which included rigid stainless steel screens and filter paper discs on top and bottom to restrict swelling and retain soil particles during $\mathrm{K}_{\mathrm{s}}$ determination. The $30-\mathrm{mm}$ tall $\mathrm{x} 54-\mathrm{mm}$ diameter brass rings of the Tempe cells were packed with the dried, sieved soil by incrementally adding 10-mm soil depths and tapping the sides of the assembly with a wooden dowel to aid in packing. Between each addition of soil to the ring, the previous packed layer was partially disturbed on its surface to prevent formation of a defined boundary between the layers. The assembled Tempe cells were weighed before and after soil packing to allow determination of bulk density (Table 1).

A manifold of plastic tubing and shutoff valves was used to allow $\mathrm{K}_{\mathrm{s}}$ determination on 10 samples simultaneously. The cores were saturated from the bottom using a Marriott bottle reservoir of degassed distilled water. After saturation of the soil, the water flow was stopped and the outlets on the bottom of the Tempe cells were temporarily plugged. The saturated cells 
were weighed and the water-filled pore volume was calculated (Table 1). While the manifold was switched to the tops (inlets) of the cells, care was taken to eliminate all air bubbles in the water supply lines and Tempe cells. The water level of the reservoir was set to $200 \mathrm{~mm}$ above the base of the soil and water flow was started. Outflow was collected and measured at known time intervals until steady state flow was observed and $K_{s}$ calculated. After reaching steady state flow, the water reservoir was replaced with the brine and one pore volume was applied (measured outflow volume). After brine application, water was again applied to the cells until relatively constant flow was observed. Three replications were performed in this manner. On separate replications of cores, the Tempe cells were opened after brine application and $2.55 \mathrm{~g}$ of powdered gypsum was incorporated into the top $5 \mathrm{~mm}$ (a rate of $11.2 \mathrm{Mg} \mathrm{ha}^{-1}$ ) and the cores were again leached with water. Each soil was replicated three times for the non-gypsum treatments and two times for the gypsum treatments. Additionally, three replications of each soil were leached with water only to provide a non-brine check. Leachate quantity and quality samples were taken at the successive stages during the experiment; pre-brine application (PRE), during the brine application (BR), multiple times post-brine application (POST1, POST2, ..., POSTn), and if applicable, multiple times after gypsum application (GYP1, GYP2, ..., GYPn).

A subsample of each leachate sample was measured into an accurately weighed beaker and dried at $60{ }^{\circ} \mathrm{C}$. The resultant evaporite solid was weighed and the concentration of TDS was calculated. At the conclusion of leaching, the Tempe cells were dismantled and the soil was removed and oven dried. The exchangeable sodium percentage (ESP) was determined by first washing $5 \mathrm{~g}$ of soil with 3 successive washes with $33 \mathrm{ml}$ of $60 \%$ ethanol (shaken, centrifuged, 
decanted) to remove excess salt, then extracting the exchangeable sodium with ammonium acetate with subsequent atomic adsorption flame spectrophotometry analysis (Doll et al. 1989). Statistical Analysis

Statistical analysis was performed using JMP (JMP, Version 10). Analysis of variance (ANOVA) and Tukey's t-test were used to determine means and standard deviations and to determine significant $\mathrm{K}_{\mathrm{s}}$ and TDS differences between soils at a given stage and between stages for a given soil. Although the Goodness of Fit method in JMP indicated that the $\mathrm{K}_{\mathrm{s}}$ values were not normally distributed, which is the assumption made when using a t-test, the differences discussed below were highly significant ( $p$-values $<0.0001$ ) and should nevertheless be an indication of differences between mean values.

\section{RESULTS}

\section{Brine saturation}

Figure 1 shows the average $K_{s}$ and TDS data for the four soils leached with one pore volume of brine with no subsequent gypsum application. Time series charts of $K_{s}$ (Fig. 1a) show the changes in $\mathrm{K}_{\mathrm{s}}$ relative to elapsed time. In Fig. 1b, the data was also segregated into general leaching stages; pre-brine application (PRE); during brine application (BR); and multiple postbrine application stages (POST1, POST2) to present significant differences between and within leaching stage and soil. During the initial water-leaching phase (PRE), the average $\mathrm{K}_{\mathrm{s}}$ (Fig. 1b) was between 0.06 and $0.08 \mathrm{~cm} \mathrm{~h}^{-1}$ for $T_{-} U, T_{-} L$, and $B_{-} L$ soils and $0.28 \mathrm{~cm} \mathrm{~h}^{-1}$ for $B_{-} U$, indicating adequate water flow through all of the soils. These values are similar to the values from the non-brine check cores, which were leached with water only (Fig. 2a). During the application of 1 
pore volume of brine (BR), the $K_{s}$ was not significantly different $(\alpha=0.05)$ from PRE $K_{s}$. However, once distilled water was again introduced to the system (POST) and leaching was continued for an average of $15 \mathrm{~h}$ (Fig. 1a), the $K_{\mathrm{s}}$ dropped to $0.009 \mathrm{~cm} \mathrm{~h}^{-1}$ for $S_{-} L$ and $0.006 \mathrm{~cm} \mathrm{~h}^{-1}$ for B_U, a $97 \%$ reduction. After approximately another $27 \mathrm{~h}$, the $\mathrm{K}_{\mathrm{s}}$ was $0.002 \mathrm{~cm} \mathrm{~h}^{-1}$ for all soils. There was a very strong significant difference $(p$-value $<0.0001)$ between the PRE $K_{s}$ and the POST1and POST2-stage $\mathrm{K}_{\mathrm{s}}$, which took $<18 \mathrm{~h}$ after the brine source was removed to fully manifest for all soils. No significant differences in $\mathrm{K}_{\mathrm{s}}$ between soils for any given leaching stage were measured except B_U for the PRE and BR stages (Fig. 1b).

The salinity of the leachate, as indicated by the TDS concentration for the same leaching events is shown in Figs. 1c and 1d. During the PRE stage, the TDS was quite low $\left(<4 \mathrm{mg} \mathrm{L}^{-1}\right.$ for all soils), indicating very little soluble salt was present in the soil to be leached out. Similar TDS values were measured from the non-brine checks (Fig $2 b$ ). The effluent TDS concentrations started to increase only slightly (not significant at $\alpha=0.05$ ) after addition of one pore volume of brine. This indicated that the brine had filled most of the previously water filled pore space and that no preferential flow was occurring. The TDS concentration of the leachate spiked between 225000 and $250000 \mathrm{mg} \mathrm{L}^{-1}$ on the POST1 sample collection, as the infiltrating water leached the salt from the soil core. As leaching continued during the POST stages, the TDS started to decline as more salts were leached out with the distilled water. The TDS for the PRE and BR stages were not significantly different for any given soil (Fig. 1d), but the TDS concentration for the POST1 stage was significantly higher than the PRE- and BR-stage TDS ( $p$-value $<0.0001$ ). The POST2-stage TDS was also significantly lower than the POST1 TDS concentration. There was no significant difference in TDS between soils for any given leaching stage. 


\section{Brine saturation with gypsum application}

Time series $K_{s}$ and TDS data for the soils leached with 1 pore volume brine and then treated with gypsum are presented in Fig. 3. Leaching was continued for a longer time (Fig. 3a) compared to the non-gypsum treatments in order to see if the gypsum would have any remedial effect on $K_{s}$. Initial PRE stage $K_{s}$ values (Fig. $3 b$ ) ranged between 0.04 and $0.08 \mathrm{~cm} \mathrm{~h}^{-1}$ for all soils. These values were slightly different but in the same range as all soils except B_U during the non-gypsum reps. The initial $K_{s}$ for $B_{-} U$ are lower than for the non-gypsum reps of the study in response to the cores being packed to a slightly higher bulk density $(1.31 \pm 0.006$ vs. $1.42 \pm 0.0$, respectively). Similar to the non-gypsum treated cores, PRE and BR $K_{s}$ were not significantly different within each soil and immediately started to decrease in the POST1 stage of leaching. At about $90 \mathrm{~h}$, the flow of water was stopped and the Tempe cells were opened to allow incorporation of $2.5 \mathrm{~g}$ of powdered gypsum (equivalent to $11.2 \mathrm{Mg} \mathrm{ha}^{-1}$ ) into the upper 5 $\mathrm{mm}$ of the soil. When leaching with water continued after gypsum application for multiple post-gypsum leachate measurement stages (GYP1, GYP2,..., GYP6) the $K_{s}$ remained low, about $0.002 \mathrm{~cm} \mathrm{~h}^{-1}$, until the end of the experiment at $450 \mathrm{~h}$.

The leachate TDS concentrations were $<2 \mathrm{mg} \mathrm{L}^{-1}$ for all soils for the PRE stage (Figure 2d). After brine application the TDS increased slightly but was only significantly higher for S_L. Then, in the POST1 stage, only 2-4 h after the brine source was removed and water flow was started (Fig. 2c), the TDS peaked at $>240000 \mathrm{mg} \mathrm{L}^{-1}$ for all soils. The TDS then started to decline as more water was leached through the soils, removing much of the salt during the POST stages. After gypsum application the TDS from all soils continued to decline from $<30 \mathrm{mg} \mathrm{L}^{-1}$ to 
about $5 \mathrm{mg} \mathrm{L}^{-1} 360 \mathrm{~h}$. However, only S_L and B_U were significantly different between the GYP1 and GYP6 stages.

\section{Exchangeable sodium}

After leaching with water, the soil cores without applied gypsum were analyzed for sodium and ESP was determined (Table 2). For all soils, the ESP was significantly higher in the cores which had been saturated with brine versus those which received no brine.

\section{DISCUSSION}

The $K_{s}$ was not significantly affected while the brine was being leached through the soil cores. Even after three pore volumes of brine was leached through the cores, no significant change in $\mathrm{K}_{\mathrm{s}}$ was observed during the actual brine application (data not shown). This was due to the high salinity maintaining clay flocculation and aggregate stability during brine leaching (Pearson 2003). However, $\mathrm{K}_{\mathrm{s}}$ was reduced to about $0.004 \mathrm{~cm} \mathrm{~h}^{-1}$ in $<20 \mathrm{~h}$ after leaching with distilled water.

For the non-gypsum cores, the POST1 leachate samples were taken between 12-18 $\mathrm{h}$ after the brine source was removed. As the leachate TDS increased to $>225000 \mathrm{mg} \mathrm{L}^{-1}, \mathrm{~K}_{\mathrm{s}}$ had already decreased to $0.01-0.006 \mathrm{~cm} \mathrm{~h}^{-1}$. Similarly, for the gypsum cores, approximately $18 \mathrm{~h}$ after the brine source was removed, water application caused the $\mathrm{K}_{\mathrm{s}}$ to decrease between 87$97 \%$, depending on the soil. After $42 \mathrm{~h}, \mathrm{~K}_{\mathrm{s}}$ had decreased another order of magnitude, to approximately $0.001-0.002 \mathrm{~cm} \mathrm{~h}^{-1}$, and remained steady throughout the remainder of the study, even though the TDS concentration of the leachate indicated that most of the salt had been removed from the soil. The fact that $K_{s}$ was not negatively affected during the brine saturation phase, but only after distilled water was applied, indicated that the high salinity 
maintained the soil structure. However, the clay and organic matter exchange sites had become saturated with sodium (high ESP), which caused dispersion and swelling to occur after the salinity had been reduced (as indicated by the decrease in leachate TDS). Others have reported clay dispersion and reduced infiltration $/ K_{s}$ when soil with high levels of sodium is leached with low EC waters (Abu-Sharar et al. 1987; Agassi et al. 1981; Shainberg et al. 1981; Suarez et al. 2008). In addition, soil swelling will also likely reduce water flow (Curtin 1994; He et al. 2015). Since the project was not continued until $\mathrm{K}_{\mathrm{s}}$ started to recover, it is unknown how long, if ever, it would take to remediate the dispersed soil. Others have indicated as many as 30 pore volumes was necessary to replace and leach sodium with calcium using a saturated gypsum solution (Jury and Weeks 1978). What is clear, however, is that once distilled water was applied to the soil surface after removal of the brine source, soil dispersion and/or swelling rapidly hindered water movement. Subsequent application of gypsum to the top $5 \mathrm{~mm}$ did not result in restoration of desirable water movement through the affected soil. However, it is unknown if a higher rate of gypsum would have been successful in replacing sodium and restoring the permeability of the soil but this is not likely mainly due to the low EC that results from a saturated solution of gypsum $\left(2.2 \mathrm{dS} \mathrm{m}^{-1}\right)$. Although others have calculated a gypsum requirement in excess of $50 \mathrm{t} \mathrm{ha}^{-1}$ for brine contaminated soils (Ashworth et al. 1999), to limit disturbance of the soil in the Tempe cells and to be able to reassemble the Tempe cells after gypsum application, a lower rate was necessary for the current study.

Based on our results, one can hypothesize about the course of events in a field brine spill scenario. During a release of brine from a tank or pipe, the salinity of the affected soil would be very high which would maintain clay flocculation as brine continues to leach into the 
soil and subsoil, thus allowing for deep percolation as long as there is a head of pressure. It also may allow a leak to remain undetected for longer periods of time since there would be less potential for surface ponding of the brine. After the pressure head of brine is removed, rainfall, irrigation, or flooding with low salinity water would likely leach some salts from the surface soil to lower soil depths before infiltration was reduced. With the reduced salinity of the soil solution and the presence of excess sodium remaining on the exchange sites, the smectitic clays would swell and dispersed clay particles would plug soil pores (Abu-Sharar et al. 1987; Curtin et al. 1994; Frenkel et al. 1978) and the surface soil would effectively be sealed. Subsequent remediation attempts using surface applied gypsum and excess water applications may be futile at that point, as the soil structure will have already been deteriorated and water movement, which is necessary to transport any sodium that may be replaced from the exchange complex with calcium, will have been drastically reduced. Once the topsoil became impermeable, no further leaching of salts from the subsoil could occur. Given the resultant degraded water movement, subsurface tile drainage would not be effective in removing additional salinity. Gypsum must be applied before the soil structure has deteriorated due to dispersion, while the saline water is still in the soil (Schofield and Taylor 1961). Of course, many variables are present in nature which could influence the process, ranging from heterogeneous flow influenced by frozen soils (Schotanus et al. 2012) and undisturbed soils to differences in clay minerology. While all scenarios cannot be discussed, the vast extent of Barnes-complex soils (>2.1 million ha in ND) and the fact that across eco-regions, North Dakota soils are dominantly smectitic and superactive (CEC/clay >0.6), suggests that soils across much of the state would be impacted similarly after a brine spill. 


\section{CONCLUSIONS}

Soil cores were packed with Barnes-complex soils from western North Dakota and subjected to oil-field brine application. Infiltrating brine did not affect hydraulic conductivity of the soil, but subsequent water application caused swelling and dispersion, which caused a drastic reduction in $\mathrm{K}_{\mathrm{s}}$ as salinity was reduced but ESP remained high. Surface application of 11 $\mathrm{Mg} \mathrm{ha} \mathrm{a}^{-1}$ of gypsum after brine application had no effect on $\mathrm{K}_{\mathrm{s}}$ or leachate TDS over the course of the study. Given the current extent of and potential for future oil-field development in North Dakota, South Dakota, Montana, and Canada, brine spills are likely to continue to impact highly productive soils such as the Barnes series used in the current study. Environmental professionals and landowners should be educated about the impacts of brine spills and remediation challenges. Based on this work, spill remediation attempts using surface applied gypsum, flooding with low to moderate salinity water, and leaching to subsurface drains must occur prior to the reduction of EC by natural or anthropogenic events. While this project demonstrated degradation of soil structure when water was applied directly after brine, many variables may be present under actual field conditions that were not addressed with this particular study. Future brine spill-related research should include laboratory and field scale experiments to investigate different ammendments, unsaturated flow, undisturbed soil, and frozen soils. 


\section{REFERENCES}

Ashworth, J., Keyes, D. and Crépin, J.-M. 1999. A comparison of methods for gypsum requirement of brine-contaminated soils. Can. J. Soil Sci. 79: 449-455.

Abu-Sharar, T.M., Bingham, F.T., and Rhoades, J.D. 1987. Stability of soil aggregates as affected by electrolyte concentration and composition. Soil Sci. Soc. Am. J. 51: 309-314.

Agassi, M., Shainberg, I., and Morin, J. 1981. "Effect of electrolyte concentration and soil sodicity on infiltration rate and crust formation." Soil Sci. Soc. Am. J. 48:848-51.

Carter, D.L., and Fanning, C.D. 1964. Combining Surface Mulches and Periodic Water Applications for Reclaiming Saline Soils. Soil Sci. Soc. Am. Proc. 28:564-567.

Clark, C.E., and Veil, J.A. 2009. Produced water volumes and management practices in the United States. Report ANL/EVS/R-09/1. Argone, IL. Environmental Science Division, Argonne National Laboratory.

Curtin, D., Steppuhn, H., and Selles, F. 1994. Structural stability of Chernozemic soils as affected by exchangeable sodium and electrolyte concentration. Can. J. Soil Sci. 74:157164. 
Daigh, A.L.M., and Klaustermeier, A.W. 2016. Approaching Brine Spill Remediation from the Surface:A New In Situ Method. Agric. Environ. Lett. Accepted Paper, posted 01/14/2016. doi:10.2134/ael2015.12.0013.

De Jong, E. 1982. Reclamation of soils contaminated by sodium chloride. Can. J. Soil Sci. 62: 351-364.

Doll, E.C., Thomas, L.R., Nash, Z.K., and Lang, K.J. 1989. Chemical analysis of soils contaminated with oilfield brine. North Dakota State University Land Reclamation Research Center. Agricultural Experiment Station Bulletin 521. Mandan, N.D.

Frenkel, H., Goertzen, J.O., and Rhoades, J.D. 1978. Effects of Clay Type and Content, Exchangeable Sodium Percentage, and Electrolyte Concentration on Clay Dispersion and Soil Hydraulic Conductivity. Soil Sci. Soc. Am. J. 42: 32-39.

Gee, G.W., and Bauder, J.W. 1979. Particle size analysis by hydrometer: a simplified method for routine textural analysis and a sensitivity test of measured parameters. Soil Sci Soc. Am. J. 43:1004-1007.

Harris, T.M., Tapp, J.B., and Sublette, K.L. 2005. Remediation of oil-field brine-impacted soil using a subsurface drainage system and hay. Environmental Geosciences, v. 12, no. 2 (June 2005), pp. 101-113. 
Jacobson, R. (2015, January 26). Fracking brine leak in North Dakota reaches Missouri River, prompts state Democrats to call for more regulation. PBS Newshour-The Rundown.

Retrieved from http://www.pbs.org/newshour/rundown/fracking-brine-leak-north-dakotareaches-missouri-river-prompts-state-democrats-call-regulation/

$\mathrm{JMP}^{\circledR}$, Version 10. SAS Institute Inc., Cary, NC, 1989-2007.

Murphy, E.C., Kehew, A.E., Groenewold, G.H., and Beal, W.A. 1988. Leachate Generated by an Oil-and-Gas Brine Pond Site in North Dakota. Groundwater. 26:31-38.

North Dakota Department of Health. 2015. Environmental incident reports. Oilfield environmental incidents. [Online] Available www.ndhealth.gov/EHS/Spills/ [2014].

North Dakota Department of Mineral Resources. 2014. North Dakota drilling and production statistics. [Online] Available www.dmr.nd.gov/oilgas/stats/statisticsvw.asp [2016].

Rhoades, J.D., and Ingvalson, R.D. 1969. Macroscopic swelling and hydraulic conductivity properties of four vermiculite soils. Soil Sci. Soc. Am. J. 33: 364-369. 
Schofield, R.K., and Taylor, A.W. 1961. A method for the measurement of the calcium deficit in saline soils. J. Soil Sci. 12:269-275.

Schotanus, D., van der Ploeg, M.J., and van der Zee, S.E.A.T.M. 2012. Quantifying heterogeneous transport of a tracer and a degradable contaminant in the field, with snowmelt and irrigation. Hydrol. Earth Syst. Sci. 16: 2871-2882, doi:10.5194/hess-16-28712012.

Soil Survey Staff. 2011. Soil Survey Laboratory Information Manual. Soil Survey Investigations Report No. 45, Version 2.0. R. Burt (ed.). U.S. Department of Agriculture, Natural Resources Conservation Service.

Soil Survey Staff, Natural Resources Conservation Service, United States Department of Agriculture. Web Soil Survey. Available online at http://websoilsurvey.nrcs.usda.gov/. Accessed [05/20/2016].

Suarez, D.L., Wood, J.D., and Lesch, S.M. 2008. Infiltration into Cropped Soils: Effect of Rain and Sodium Adsorption Ratio-Impacted Irrigation Water. J. Environ. Qual. 37:169-179 (2008). 
Pearson, K.E. Basics of Salinity and Sodicity Effects on Soil Physical Properties. Adapted by Krista E. Pearson from a paper by Nikos J. Warrence, Krista E. Pearson, and James W. Bauder (2003).

Shainberg, I., Rhoades, J.D., and Prather, R.J. 1981. Effect of low electrolyte concentration on clay dispersion and hydraulic conductivity of a sodic soil. Soil Sci. Soc. Am. J. 45: 273-277.

Sommerfeldt, T.G., Schaalje, G.B., and Hulstein, W. 1984. Use of Tempe cell, modified to restrain swelling, for determination of hydraulic conductivity and soil water content. Can. J.

Soil Sci. 64: 265-272.

Sublette, K.L., Moralwar, A., Ford, L., Duncan, K., Thoma, G., and Brokaw, J. 2005.

Remediation of a spill of crude oil and brine without gypsum. Environ. Geosciences. 12:

115-125. 
Table 1. Initial soil and repacked soil core properties. The pore volume, calculated based on particle density $=2.65 \mathrm{~g} \mathrm{~cm}^{-3}$ and bulk density $=1.40 \mathrm{~g} \mathrm{~cm}^{-3}$, was $32.4 \mathrm{~cm}^{3} . \mathrm{n}=2$ for texture, $\mathrm{pH}, \mathrm{EC}$, and CEC. $n=5$ for core bulk density and pore volume. I, loam; sl, sandy loam.

\begin{tabular}{|c|c|c|c|c|c|c|c|c|c|}
\hline Soil & Sand & Silt & Clay & $\begin{array}{c}\text { Lab } \\
\text { texture }\end{array}$ & $\mathrm{pH}_{1: 1}$ & $\mathrm{EC}_{1: 1}$ & $\mathrm{CEC}$ & $\begin{array}{c}\text { Core bulk } \\
\text { density }\end{array}$ & $\begin{array}{c}\text { Core pore } \\
\text { volume }\end{array}$ \\
\hline & $\%$ & $\%$ & $\%$ & & & $\mathrm{dS} \mathrm{m}^{-1}$ & $\left.\mathrm{cmol}^{-3}\right] \mathrm{kg}^{-1}$ & $\mathrm{~g} \mathrm{~cm}^{-3}$ & $\mathrm{~cm}^{3}$ \\
\hline T_U & 41 & 40 & 19 & $\mathrm{I}$ & 7.46 & 0.53 & 11.22 & $1.41 \pm 0.04$ & $29.02 \pm 0.23$ \\
\hline S_L & 38 & 43 & 19 & $\mathrm{I}$ & 6.78 & 0.69 & 12.58 & $1.39 \pm 0.04$ & $29.68 \pm 1.08$ \\
\hline B_U & 42 & 41 & 17 & $\mathrm{I}$ & 7.50 & 0.50 & 9.42 & $1.36 \pm 0.06$ & $29.50 \pm 0.90$ \\
\hline B_L & 53 & 37 & 9 & $\mathrm{sl}$ & 7.38 & 0.84 & 10.32 & $1.36 \pm 0.01$ & $30.56 \pm 2.15$ \\
\hline
\end{tabular}

\pm values are standard deviation. 
Table 2. Exchangeable sodium percentage of soils after leaching experiments.

\begin{tabular}{ccc}
\hline Soil & Brine applied & Exchangeable sodium \\
\hline \multirow{2}{*}{ T_U } & pore volumes & $\%$ \\
& & \\
\multirow{2}{*}{ S_L } & 0 & 0.9 \\
& 1 & 62.8 \\
B_U & 0 & 1.0 \\
& 1 & 59.8 \\
B_L & 0 & 1.0 \\
& 1 & 56.6 \\
& 0 & 1.0 \\
\hline
\end{tabular}




\section{FIGURE CAPTIONS}

Figure 1. Time series charts of average a) saturated hydraulic conductivity $\left(K_{s}\right)$ and c) total dissolved solid (TDS) concentration of the leachate for the four soils (T_U, Tonka upland; S_L, Svea lowland; B_U, Barnes upland; B_L, Barnes lowland) leached with one pore volume brine and receiving no gypsum. Vertical lines through data points are $95 \%$ confidence intervals. Charts by leaching stage (PRE, pre-bine water application; BR, during brine application; POST, post-brine water application) of average b) saturated hydraulic conductivity $\left(\mathrm{K}_{\mathrm{s}}\right)$ and d) total dissolved solid (TDS) concentration of the leachate for the four soils leached with one pore volume brine and receiving no gypsum. Means with different lower case letters are significantly different between leaching stage for a given soil. Means with different upper case letters are significantly different between soils for a given leaching stage. Corresponding leaching stage is also indicated across top of time series chart.

Figure 2. Time series charts of average a) saturated hydraulic conductivity $\left(K_{s}\right)$ and b) total dissolved solid (TDS) concentration of the leachate for the four soils (T_U, Tonka upland; S_L, Svea lowland; B_U, Barnes upland; B_L, Barnes lowland) leached with water only. Vertical lines through data points are $95 \%$ confidence intervals.

Figure 3. Time series charts of average a) saturated hydraulic conductivity $\left(K_{s}\right)$ and c) total dissolved solid (TDS) concentration of the leachate for the four soils (T_U, Tonka upland; S_L, Svea lowland; B_U, Barnes upland; B_L, Barnes lowland) leached with one pore volume brine and receiving 11.2 $\mathrm{Mg} \mathrm{ha}^{-1}$ gypsum. Vertical lines through data points are $95 \%$ confidence 
intervals. Charts by leaching stage (PRE, pre-bine water application; BR, during brine application; POST, post-brine water application) of average b) saturated hydraulic conductivity $\left(K_{s}\right)$ and $\left.d\right)$ total dissolved solid (TDS) concentration of the leachate for the four soils leached with one pore volume brine and receiving 11.2 $\mathrm{Mg} \mathrm{ha}^{-1}$ gypsum. Means with different lower case letters are significantly different between leaching stage for a given soil. Means with different upper case letters are significantly different between soils for a given leaching stage. Corresponding leaching stage is also indicated across top of time series chart. 

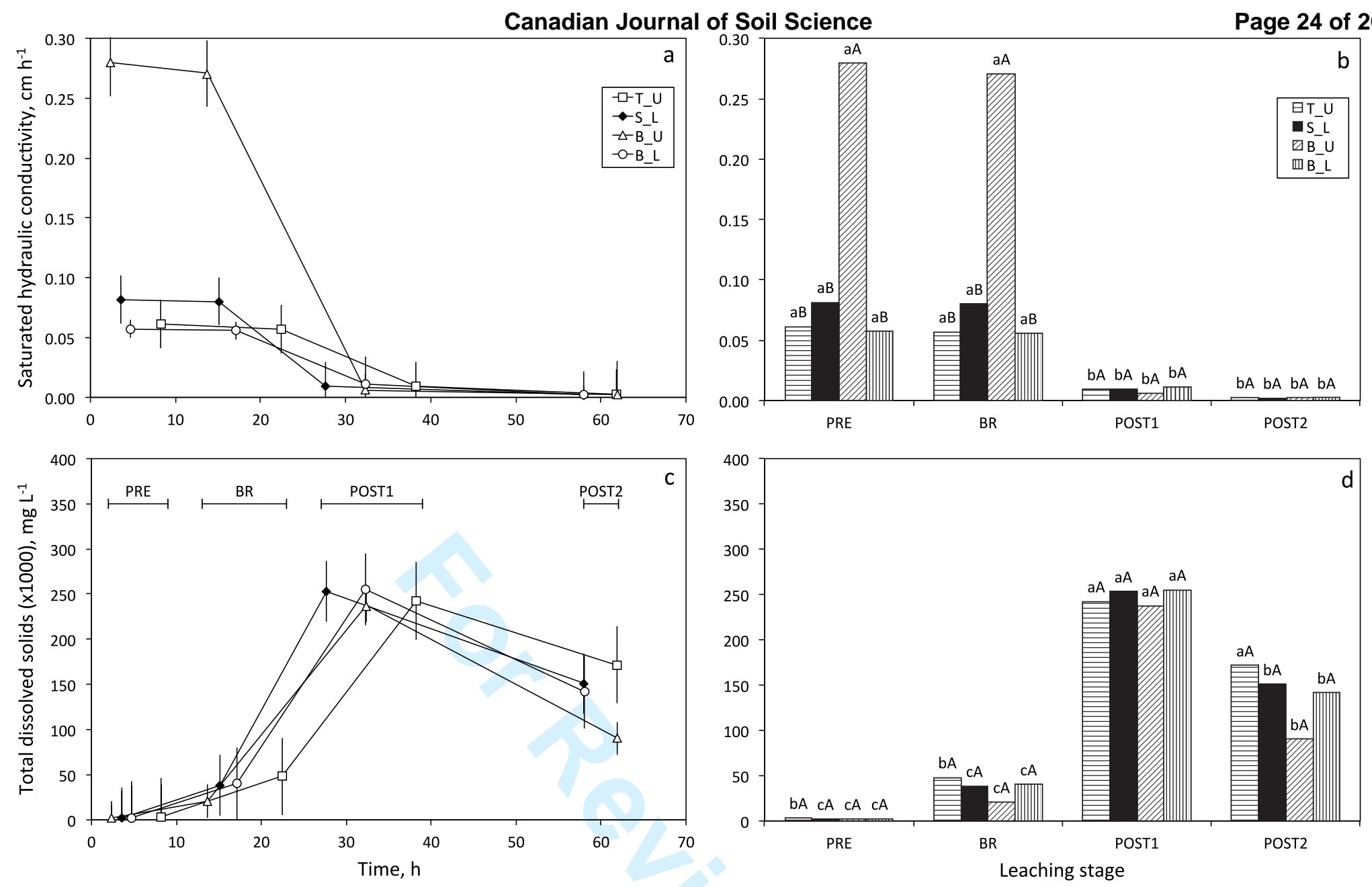


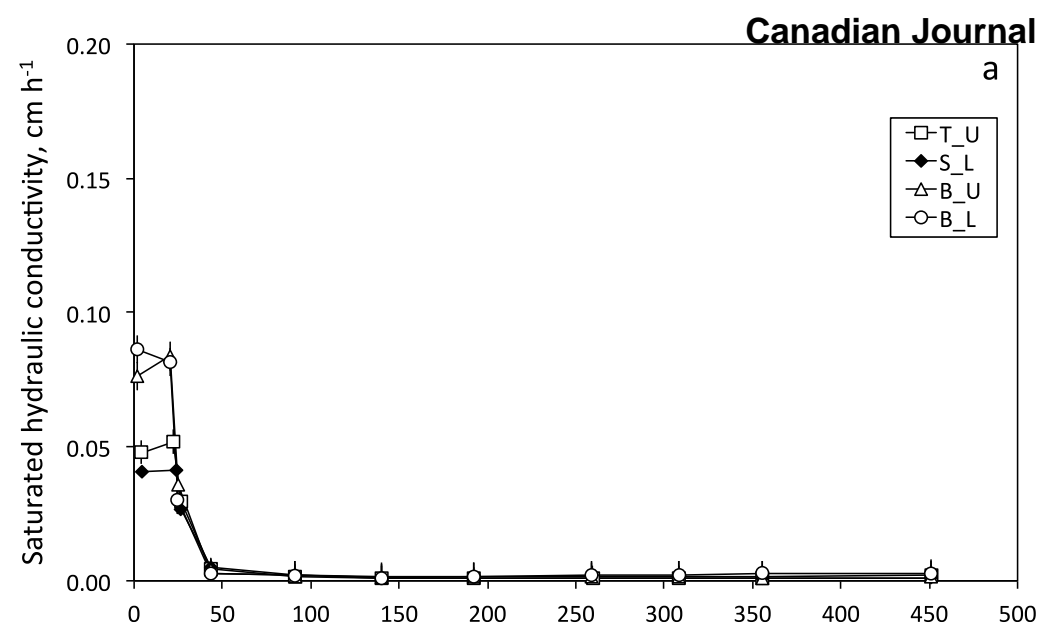

Page 26 of 26
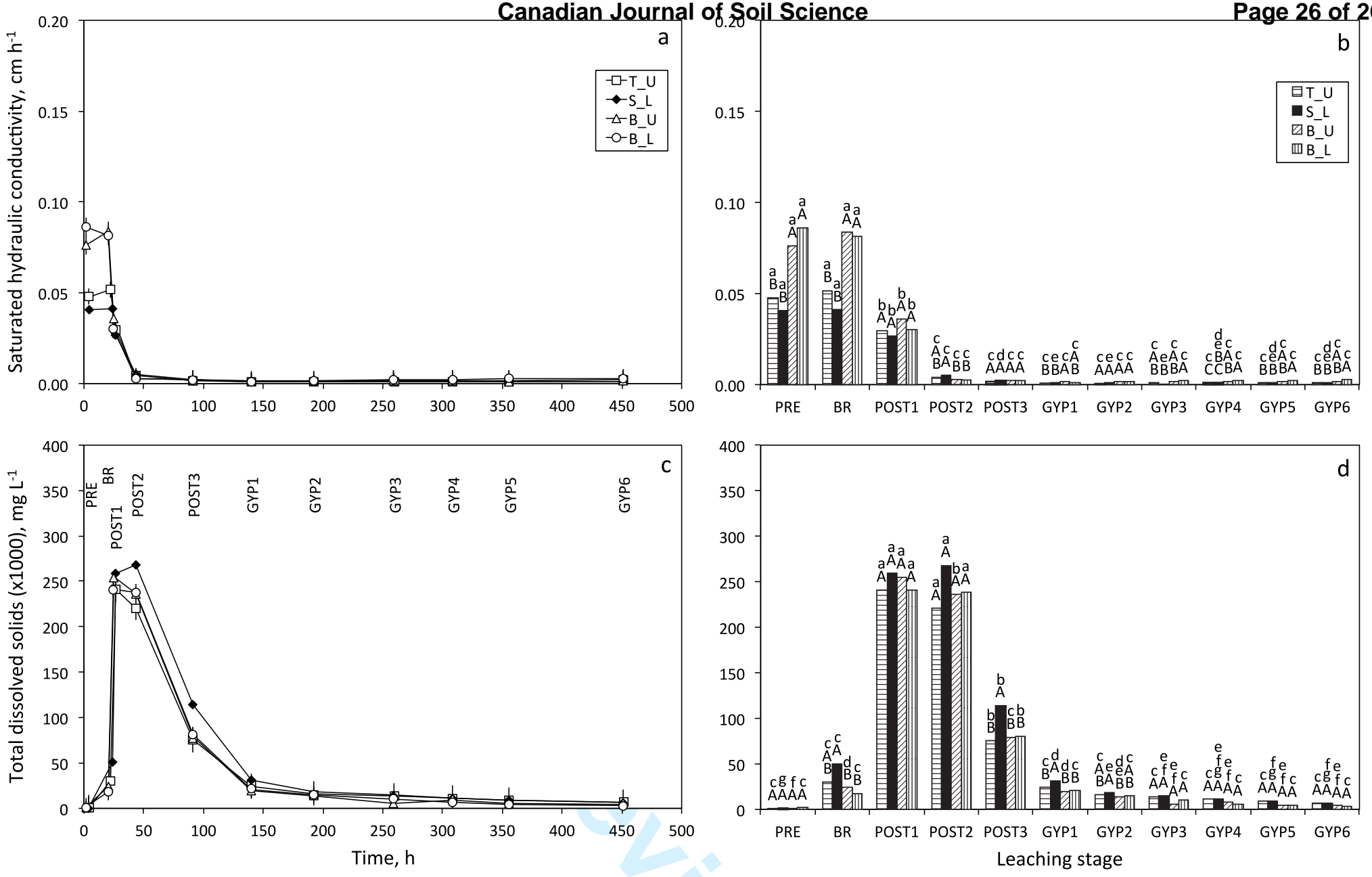